Lea, C. H. (1936). Rep. Fd Invest. Bd, Lond., p. 73 .

Lea, C. H. \& Hannan, R. S. (1950). Biochim. biophys. acta, 5, 433.

Lea, C. H. \& Parr, L. J. (1958). Proc. Nutr. Soc. 17, xxix.

Meade, T. L. (1956). Feedstuffs, 28, no. 20, p. r4.

Melnick, D. (1957). F. Amer. Oil Chem. Soc. 34, 35 I.

Miller, D. S. (1956). F. Sci. Fd Agric. 7, 337.

Nonaka, J. (1956). Bull. Fap. Soc. sci. Fish. 21, 1244.

Stansby, M. E. (1947). F. Ass. off. agric. Chem., Wash., 30, 595 .

Stansby, M. E., Brown, W. D., Venolia, A. W., Tappel, A. L., Olcott, H. S. \& Einsett, E. (1957). Comm. Fish. Rev. 19, no. 5a, p. 24 .

Tappel, A. L. (1955). Arch. Biochem. Biophys. 54, 266.

Tappel, A. L. (1956). Food Res. 2r, 195.

Witting, L. A., Nishida, T., Johnson, O. C. \& Kummerow, F. A. (1957). F. Amer. Oil Chem. Soc. 34, 421 .

\title{
Riboflavin metabolism of cows and goats and rate of biosynthesis of riboflavin by the lactating goat
}

\author{
By AUDREY CROSSLAND, E. C. OWEN AND R. PROUDFOOT \\ Hannah Dairy Research Institute, Kirkhill, Ayr
}

(Received 8 February 1958)

In previous experiments from this laboratory Edwards \& Darroch (1956) showed that lactating goats could be kept in positive nitrogen balance while excreting in their milk more lysine than was in their food. They therefore concluded that the goat must have synthesized lysine by the aid of alimentary symbionts (Owen, I954; Edwards, 1955) and that the amount of lysine synthesized was at least as great as the excess of the lysine output in milk and urine over the dietary lysine.

The diet used in these experiments was not only deficient in lysine, but was also very deficient in the water-soluble vitamins of the B-group. It was therefore a suitable diet for studying the synthesis of these vitamins, and in the experiments about to be described the synthesis of riboflavin by the lactating goat was measured.

Preliminary experiments showed that chemical methods published hitherto for determining riboflavin in urine were not specific. The partition of lyochromes in the urine of cows and goats was therefore studied and a chemical method specific for riboflavin was worked out.

EXPERIMENTAL

\section{Estimation of nitrogen}

In the food, milk, urine and faeces nitrogen was estimated by the Kjeldahl method with a mixture of $\mathrm{K}_{2} \mathrm{SO}_{4}, \mathrm{CuSO}_{4}$ and $\mathrm{Se}$ as catalyst.

\section{Analytical procedure}

\section{Estimation of riboflavin and its derivatives}

Riboflavin was estimated fluorimetrically and the fluorimetric results were checked by the microbiological method of Snell \& Strong (1939a) in the medium of Barton- 
Wright \& Booth (1943), with Lactobacillus casei (National Collection of Industrial Bacteria, 8010) as test organism.

Pure synthetic riboflavin was used to make standard solutions which were checked by measurement of their optical densities at $450 \mathrm{~m} \mu$ in a Unicam SP 500 spectrophotometer.

\section{Description of fluorimeter}

A fluorimeter (Fig. I) of the type recommended by Lowry (I948) was built in the laboratory for these experiments and some features of it are worthy of note.

A stable source of light, worked from the a.c. mains, was found in the Philips $\mathrm{MBL} / \mathrm{U}, 125 \mathrm{~W}, 250 \mathrm{~V}$ mercury-vapour lamp (Holloway, I956). We housed the lamp in an aluminium chimney $3^{6} \mathrm{~cm}$ long, both to dissipate the heat of the lamp by

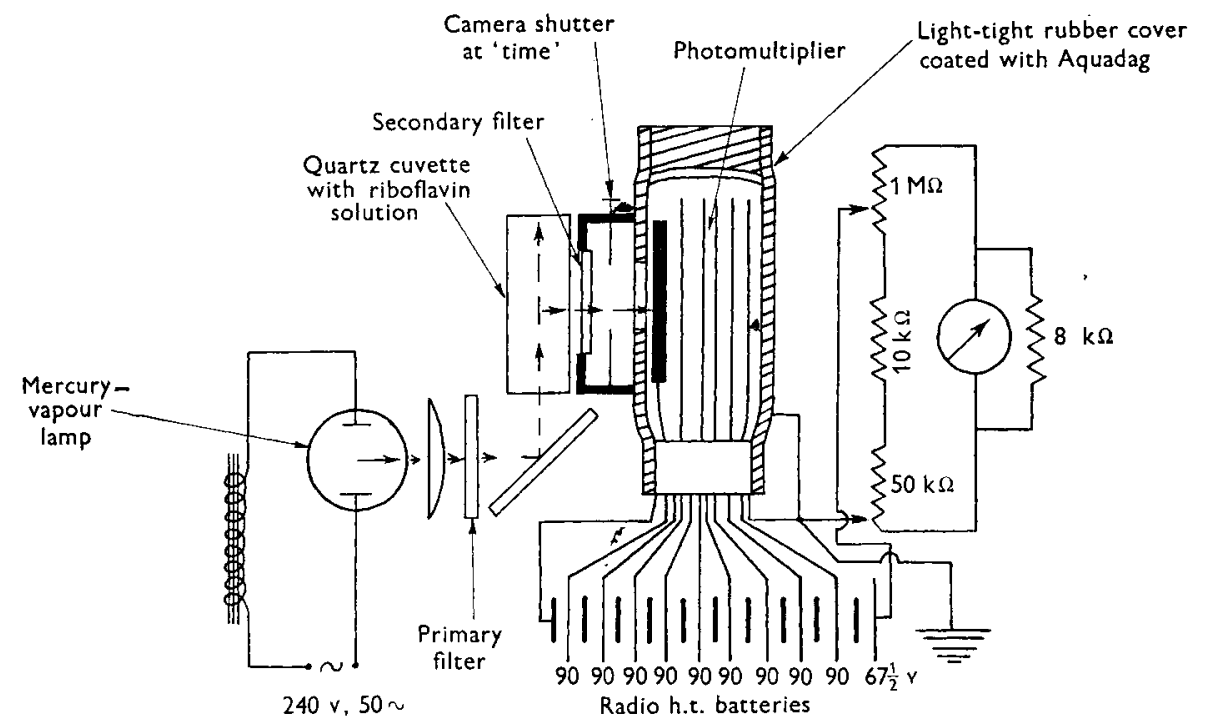

Fig. I. Diagram of fluorimeter.

convection of air from below it and to act as a screen to keep stray ultraviolet light from the eyes of the operator. The exciting beam passes through a hole in the chimney, through a heat-absorbing glass filter $\left(\mathrm{H}_{5} \mathrm{O}_{3}\right.$, Hilger \& Watts Ltd, London) and then through a Kodak no. 2 violet filter with a peak transmission at $430 \mathrm{~m} \mu$, so that the chief exciting wavelength is the $435.8 \mathrm{~m} \mu$ line of the mercury-vapour spectrum. It is then collimated and deflected by a $45^{\circ}$ mirror so as to enter the quartz cuvette, holding the riboflavin solution, vertically through its base. Fluorescent light is received perpendicularly to the exciting beam, through a green secondary filter, directly on to the photocathode of a photomultiplier tube RCA93 I with no intervening lens system. The green filter which was selected by visual examination with a hand spectroscope of the fluorescence of pure riboflavin in aqueous solution is a combination of three filters of the Wratten type. One of these filters is green with a peak transmission at $526 \mathrm{~m} \mu$, one blue with a peak transmission at $477 \mathrm{~m} \mu$ and one yellow transmitting between $55^{\circ}$ and 
$650 \mathrm{~m} \mu$. The combination gives a narrow band of transmission with a peak at 5 10 $\mathrm{m} \mu$. An interference filter with this transmission would probably have been ideal but was not readily obtainable. Stray light is prevented from reaching the photocathode by a brass ring mounted between the vertical wall of the quartz cuvette and the aperture between the cuvette-holder, which has a light-tight closable cover, and the photomultiplier tube. Between the cuvette-holder aperture (see Fig. I) and the photomultiplier is a camera shutter which assists in keeping out stray light. The shutter is used at full aperture, since riboflavin is not excessively fluorescent. The shutter is kept set at 'time' so that one operation of the lever opens it and the next shuts it again, which minimizes the possibility of damage to the tube from accidental illumination. Each of

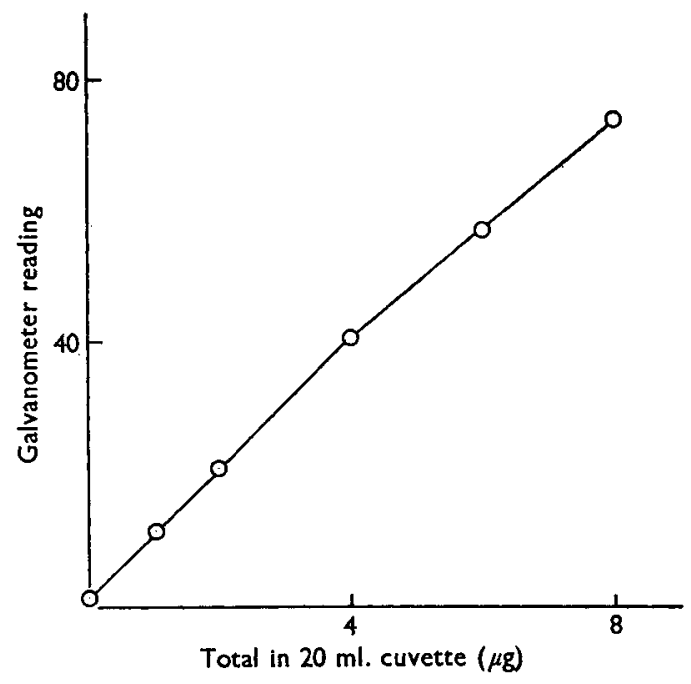

Fig. 2. Calibration of the fluorimeter. Each point, except the one of the origin, represents the reading from a standard solution of riboflavin in water. The point at the origin is for distilled water.

the first nine stages of the photomultiplier is powered by a $90 \mathrm{v}$ dry battery and the tenth (final) stage by a $67 \frac{1}{2} \mathrm{v}$ dry battery, both types of battery being readily obtained from any radio retailer. The batteries are housed in a wooden box coated with paraffin wax and are separated from one another by pieces of cardboard impregnated with paraffin wax. All the leads from the photomultiplier except the one from the final anode are in a multicore cable. The lead from the final anode is insulated with Polythene and earthed together with that from a conducting but light-tight blanket which covers the photomultiplier tube (see Fig. I). This covering is made from rubber tubing closed at the top with a rubber bung. To a circular hole in the side of the rubber tubing a second piece of rubber tubing is sealed to make a light-tight joint between the camera shutter and the aperture in front of the photocathode. The outside surface of the rubber is rendered conductive by a coating of Aquadag (Acheson's Colloids Ltd, Plymouth). The output of the photomultiplier is measured with a spot galvanometer (Cambridge Instrument Co. Ltd, London), which has a $\mathrm{I} 6 \mathrm{~cm}$ scale and a sensitivity in use of $16 \mathrm{~cm} / \mu \mathrm{A}$. When the fluorimeter is not in use the multicore cable from the photo- 
multiplier can be disconnected from the high-tension batteries. For this purpose the leads from the batteries are all permanently connected to a multipoint socket mounted on a Perspex insulator, into which the multicore cable can be plugged. The final anode also can be disconnected by release of a spring clip. The fluorimeter is housed in the dark room in which riboflavin extractions are carried out.

The performance of the fluorimeter was tested by means of aqueous solutions of pure riboflavin $\left(\mathrm{pH}_{5}\right)$. A typical calibration curve is that in Fig. 2, which shows that the response of the instrument was almost linear over the range of concentration used. The instrumental blank was negligible as shown by the position of the reading for distilled water at the origin. The fluorescence of solutions was measured with an internal standard (Bessey, Lowry \& Love, 1949). Koschara (I934) showed that sodium dithionite $\left(\mathrm{Na}_{2} \mathrm{~S}_{2} \mathrm{O}_{4}\right)$ reduces lyochromes to leuco-forms which do not fluoresce. The fluorescence was therefore quenched with sodium dithionite to give a blank reading.

\section{Electrophoresis of riboflavin and its derivatives}

A strip $(45 \times 2 \mathrm{~cm})$ of Whatman no. 3 filter-paper was clamped between two rectangular plates of glass $(26 \times 4 \times 0.3 \mathrm{~cm})$ which had been rendered permanently water-repellent by subjection to an atmosphere containing dimethyldichlorosilane vapour in a desiccator. Collars, one at each end, and two wedges in each collar all made of Perspex served to hold the strip of paper firmly between the two glass plates. The strip of paper was moistened with the buffer solution and the excess solution was removed with blotting paper. The paper was then placed in position on the lower plate and the spot of flavin concentrate applied at the marked origin. The upper plate was then clamped on and the plates were placed on a set of copper tubes through which cooling water circulated. The ends of the paper dipped into Perspex troughs containing $0.05 \mathrm{M}$ borate buffer of $\mathrm{pH} 9.2$ into which the current was led by platinum wire. The apparatus could take four strips at once. For rapid choice of buffer solutions, a Kawerau (195 I) apparatus, entirely of glass with B 34 standard joints and $50 \mathrm{ml}$. flasks, was fitted with a water-repellent glass plate and a cooling tube. Electrophoresis was continued for $17 \mathrm{~h}$ at $130 \mathrm{~V}$ which produced a current of $0.5 \mathrm{~mA} / \mathrm{cm}$ width. The separated spots were made visible by ultraviolet light from a Sieray $125 \mathrm{~W}$ mercury-vapour lamp (Siemens Electric Lamps and Supplies Ltd, London), for which a ventilated aluminium box with a Wood's glass window was built in the Institute's workshop.

\section{Paper chromatography of riboflavin and its congeners}

The system of Crammer (1948) was used with Whatman no. 3 I paper. Water, glacial acetic acid and $n$-butanol, 5:I:4, are shaken together. The lower, more aqueous layer is put into beakers at the bottom of the chromatography chamber to saturate the atmosphere, and the upper layer is used to develop the chromatogram. With a warm air draught to aid evaporation, up to $30 \mu \mathrm{l}$. of aqueous concentrate may be applied to the paper. On no. $3^{\mathrm{I}}$ paper the chromatograms are run for $6 \mathrm{~h}$. For smaller amounts of concentrates chromatograms are run for $24 \mathrm{~h}$ on no. I paper. $R_{F}$ values of riboflavin in extracts prepared from urine are greater than those of riboflavin in pure solution, so that a 
control has to be run of a duplicate extract to which riboflavin has been added. There is a certain amount of trailing of very concentrated urine extracts but not with pure riboflavin. The smaller the amounts applied the less tendency there is to trail.

\section{Chromatography on Floridin columns}

Electrophoresis and chromatography on paper were used for identification and separation of riboflavin and its congeners, but, for quantitative measurements of riboflavin in food, urine and faeces, chromatography on columns containing Floridin XS (British Drug Houses Ltd) was used. Removal of the finer particles of the Floridin by washing with water before use served to increase the rate of passage of the liquids through the column. Portions of the aqueous extracts containing 2-10 $\mu$ g riboflavin were diluted to $5 \mathrm{ml}$., adjusted to $\mathrm{pH} 5$ with glacial acetic acid and then poured on to the $15 \times 1 \mathrm{~cm}$ acid-treated column (Ferrebee, 1940). Air pressure applied to the top of the column produced an efflux of I ml./min. After the riboflavin had been adsorbed the column was washed with water which freed the adsorbate from the remaining blue-fluorescing impurities. Riboflavin was then eluted with $50 \mathrm{ml} .20 \%$ $(\mathrm{v} / \mathrm{v})$ pyridine in $2 \%(\mathrm{v} / \mathrm{v})$ acetic acid. The column was regenerated by washing it with hot water $(5 \circ \mathrm{ml}$.) followed by $2 \%(\mathrm{v} / \mathrm{v})$ acetic acid $(50 \mathrm{ml}$.) and distilled water (50 ml.).

\section{Estimation of riboflavin in milk, urine, rumen contents, foods and faeces}

Milk. Milk was analysed for total riboflavin by the method of Bessey et al. (1949). In this method the fluorescence of the riboflavin was measured directly in the supernatant liquid from a precipitation of the milk with trichloroacetic acid, the extract being allowed to stand overnight in the dark at $38^{\circ}$ until all the compounds of riboflavin had been hydrolysed to free riboflavin, which was then measured fluorimetrically after neutralization.

Urine. Acidified urine (100 $\mathrm{ml}$.) was saturated with $\mathrm{NaCl}$ and extracted twice, first with 15 and then with $5 \mathrm{ml}$. previously melted A.R. phenol. Addition of the $\mathrm{NaCl}$ increased the efficiency of the extraction by facilitating the separation of the aqueous from the phenolic phase and by obviating interference due to natural variations of the density of urine. With $\mathrm{NaCl}$ the phenol phase is always uppermost (Greene \& Black, 1937). Addition of ether to the separated phenol layer threw out a concentrated aqueous phase containing all the lyochromes. This aqueous phase was chromatographed on Floridin XS as already described.

Foodstuffs, rumen contents and faeces. These were incubated (Lewis \& Gorham, 1947) at $37^{\circ}$, with constant agitation for $16 \mathrm{~h}$ in an acetate buffer at $\mathrm{pH} 4.6$ containing $0.4 \%$ of a mixture of equal parts of papain and Takadiastase (Parke Davis and Co. Ltd, Middlesex). The filtered extracts were then chromatographed on Floridin XS as already described, instead of being further treated, as Lewis \& Gorham suggested, with $\mathrm{SbCl}_{3}$. From our materials $\mathrm{SbCl}_{3}$, unlike Floridin XS, did not eliminate interfering pigments and fluorescent impurities. The final estimation of riboflavin in all materials was fluorimetric, but with every material the reliability of this method was subjected to a preliminary microbiological check. 


\section{Xanthine oxidase}

Milk that had been stored at $-18^{\circ}$ was thawed at $37^{\circ}$, homogenized and diluted to five times its volume. Of the diluted milk I $\mathrm{ml}$. was taken and tested exactly as described by Zittle, Dellamonica, Custer $\&$ Rudd (i956), the formazan resulting from the reduction of the $2: 3: 5$-triphenyltetrazolium chloride by the xanthine oxidase being extracted into $4 \mathrm{ml}$. toluene. The optical density of the resulting solution of the formazan in the toluene was measured in a Unicam spectrophotometer at $485 \mathrm{~m} \mu$. Dispensing of the diluted homogenized milk from syringes instead of pipettes improved the duplication.

\section{Preparation of the diet}

The diet was similar to that used by Edwards \& Darroch (1956) and consisted of zein 17.4 , potato starch 34.7 , alkali-treated straw 34.7 , treacle 8.7 , urea 0.5 and salt mixture $4 \%$. The treatment of the straw with alkali was as described by Edwards $\&$ Darroch (1956). The salt mixture, like that of Edwards \& Darroch, contained both zinc and cobalt, but also had 37 p.p.m. of ammonium molybdate added to it. This addition was made since Mo is an essential constituent of certain enzymes, in particular of xanthine oxidase which occurs in goat's milk in appreciable amounts (Modi \& Owen, I956). The food, devoid of riboflavin, was given to all four goats along with alkalitreated oat straw and paper pulp as roughage. Goats nos. 3 and 4 acted as positive controls for they were given by dosing gun, every second day, $30 \mathrm{mg}$ pure riboflavin (British Drug Houses Ltd). A capsule containing $50 \mathrm{mg} \alpha$-tocopheryl acetate in $0.5 \mathrm{ml}$. olive oil and $30 \mathrm{ml}$. oil supplied by Glaxo Laboratories Ltd and containing 2000 i.u. vitamin $A$ and 200 i.u. vitamin $\mathrm{D}_{2} / \mathrm{ml}$. were administered to each goat every second day.

\section{Management of the animals and collection of samples}

Goats. The animals used for the measurement of riboflavin biosynthesis were British Saanen goats. No. I was 6 years old and in its fourth lactation, nos. 2, 3 and 4 were 4 years old and in their second lactation. The animals were changed gradually from their previous diet which consisted of a mixture of oats, beans and dried grass $(3: 2: \mathrm{x})$ to the experimental ration, and daily collections of excreta and milk were begun as soon as the goats were eating the new ration without leaving much of it. The food was given in $500 \mathrm{~g}$ lots, three times daily, at early morning milking, at noon and at evening milking. With each allowance of meal an allowance of alkali-treated oat straw and of dried paper pulp made from wheat straw (Straw Pulp Manufacturing Co. Ltd) were given. The actual amounts eaten varied from day to day, but refused food was collected every day, dried, allowed to equilibrate with the atmosphere and weighed. Intakes of nitrogen and riboflavin were corrected for these refusals. The corrections for riboflavin were negligible because the concentration of riboflavin in the diet was so small.

The goats were confined in crates in which they could be milked. Urine and faeces fell on to an inclined white polyvinyl-chloride plastic plate. This plate was drilled over its whole surface with holes which allowed the urine to run through, but the plate retained the faeces which rolled to a ledge on its lower edge. A galvanized iron funnel 
directed the urine into a Polythene bottle containing $100 \mathrm{ml} .2 \mathrm{I} \%(\mathrm{w} / \mathrm{v}) \mathrm{HCl}$ as a preservative (see Pl. I). Pending analysis for riboflavin all samples of food, milk, urine and faeces were kept at $-18^{\circ}$.

Samples of rumen contents taken from the goats by stomach pump on 3 different days were compared with samples taken from the same goats when fed on the same deficient diet in a later experiment and with samples from four other British Saanen female goats of the same herd eating a ration of beans, oats, dried grass and hay. The apparatus designed for obtaining these rumen samples is shown in P1. 2.

In studies of the lyochromes urine was collected from four other British Saanen goats.

Cattle. Urine was examined from a young Ayrshire bull, from four cows of the Ayrshire herd at the West of Scotland Agricultural College, Auchincruive, and from a group of lactating Ayrshire cows at the Hannah Institute before they went out to grass in May and while they were grazing during the ensuing summer and autumn. Urine from cows which were stall-fed all the year round was also examined.

\section{RESULTS}

\section{Recovery of riboflavin added to urine}

The first part of Table I shows that recovery of riboflavin added to urine before extraction with phenol was satisfactory. The second part shows a similarly satisfactory recovery when the riboflavin was added to the urine concentrate after the extraction with phenol and treatment with ether.

\section{Table I. Recovery of added riboflavin, measured fluorimetrically, from goat's urine}

\begin{tabular}{|c|c|c|c|c|c|}
\hline \multicolumn{3}{|c|}{$\begin{array}{l}\text { Phenol extraction, adsorption on Floridin XS } \\
\text { and elution with pyridine-acetic acid }\end{array}$} & \multicolumn{3}{|c|}{$\begin{array}{c}\text { Adsorption on Floridin XS and elution with } \\
\text { pyridine-acetic acid }\end{array}$} \\
\hline \multirow{2}{*}{\multicolumn{2}{|c|}{ Riboflavin $(\mu \mathrm{g})$}} & \multirow{3}{*}{$\begin{array}{l}\text { Recovery of } \\
\text { added } \\
\text { riboflavin } \\
(\%)\end{array}$} & \multicolumn{2}{|c|}{ Riboflavin $(\mu \mathrm{g})$} & \multirow{3}{*}{$\begin{array}{l}\text { Recovery of } \\
\text { added } \\
\text { riboflavin } \\
(\%)\end{array}$} \\
\hline & & & & $\mathrm{Iml}$ urane & \\
\hline $200 \mathrm{ml}$. urine & $\begin{array}{l}200 \mathrm{ml} \text {. urine }+ \\
50 \mu \mathrm{g} \text { riboflavin }\end{array}$ & & $\begin{array}{l}\text { I ml. urine } \\
\text { concentrate }\end{array}$ & $\begin{array}{c}\text { concentrate }+r o \mu g \\
\text { riboflavin }\end{array}$ & \\
\hline \multirow[t]{2}{*}{$\left.\begin{array}{l}439 \cdot 3 \\
429 \cdot 0\end{array}\right\} 434 \cdot 2$} & $\begin{array}{l}489 \cdot 0 \\
486 \cdot 0\end{array}$ & $\begin{array}{l}109 \cdot 6 \\
103 \cdot 6\end{array}$ & $\left.\begin{array}{l}25 \cdot 6 \\
29 \cdot 1\end{array}\right\} 27 \cdot 4$ & $39 \cdot 3$ & II 9 \\
\hline & & & $\left.\begin{array}{l}20 \cdot 9 \\
23 \cdot 3\end{array}\right\} 22 \cdot 1$ & $31 \cdot 0$ & 89 \\
\hline $100 \mathrm{ml}$. urine & $\begin{array}{l}\text { I00 } \mathrm{ml} \text {. urine }+ \\
200 \mu \mathrm{g} \text { riboflavin }\end{array}$ & 一 & $\begin{array}{l}\text { I } \mathrm{ml} \text {. urine } \\
\text { concentrate }\end{array}$ & $\begin{array}{l}1 \mathrm{ml} \text {. urine } \\
\text { concentrate }+50 \mu \mathrm{g} \\
\text { riboflavin }\end{array}$ & - \\
\hline \multirow{3}{*}{$\left.\begin{array}{l}512 \cdot 5 \\
538 \cdot 0\end{array}\right\} 525 \cdot 3$} & $722 \cdot 0$ & $98 \cdot 4$ & $\left.83^{\circ} 6\right\}_{83}$ & 128.9 & 90.8 \\
\hline & $7 \mathrm{II} \cdot 0$ & $92 \cdot 9$ & $83 \cdot 3\}^{03}$ & $128 \cdot 5$ & $90 \cdot 0$ \\
\hline & $753^{\circ} 0$ & II 3.9 & - & $130 \cdot 7$ & $94 \cdot 4$ \\
\hline
\end{tabular}

Table 2 shows a comparison of the chemical and microbiological methods of estimating riboflavin in urine. The chemical results were slightly in excess of the microbiological. Without the final Floridin adsorption the estimation of the riboflavin in the urine concentrate was not possible. An electropherogram of the urine concentrate from the goats on the experimental diet showed, before Floridin treatment, one spot of 
riboflavin and three blue-fluorescing substances. Paper electropherograms showed that two of the blue-fluorescing substances passed through the column before the pyridineacetic-acid eluant was added.

Table 2. Comparison of chemical and microbiological methods for estimating riboflavin in urine of goats

Microbiological $(a)$
$(\mu \mathrm{g} / \mathrm{ml}$.
$1 \cdot 52$
$1 \cdot 51$
$1 \cdot 58$
$\mathrm{I} \cdot 53$

$\begin{array}{cc}\begin{array}{c}\text { Chemical }(b) \\ (\mu \mathrm{g} / \mathrm{ml} .)\end{array} & \begin{array}{c}a \text { as a } \\ \text { percentage of } b \\ \mathrm{I} \cdot 79\end{array} \\ \mathrm{I} \cdot 75 & 84 \cdot 9 \\ \mathrm{I} \cdot 8 \mathrm{o} & 86.4 \\ \mathrm{I} \cdot 8 \mathrm{z} & 87.8\end{array}$

\section{Riboflavin-like substances (lyochromes) in urine}

Before the balance of riboflavin was measured the nature of the lyochromes in urine had to be investigated. The urine of cows and goats fed on grass or on winter diets was found to contain a variety of phenol-extractable substances with yellow fluorescence in ultraviolet light (Crossland, Owen \& Proudfoot, I958). The results of these investigations are summarized in Table 3 which shows that ruminant urine may contain up to four lyochromes. These lyochromes are all acid-resistant and all have a yellow fluorescence in ultraviolet light which is quenched by addition of sodium dithionite. Of these substances only two, riboflavin and riboflavin metabolite, were found in acidtreated milk, the acid treatment serving to free riboflavin from its combination in flavinadenine dinucleotide in the milk, but having no apparent effect on what we have called, in Table 3 , riboflavin metabolite.

Urine and milk from goats fed on grass, winter rations or the riboflavin-free diet were examined. Table 3 presents results obtained with all the animals, both goats and cows, listed in the section on management of animals. Of the lyochromes, substance $I$, grass metabolite and riboflavin metabolite, none could have been confused with riboflavin when we were measuring the rate of synthesis of riboflavin by goats on the deficient diet, because urine or milk from goats on the deficient diet contained only riboflavin and because the amount of supplement given to the control animals ( $5 \mathrm{mg}$ riboflavin/day) was found to be insufficient to produce a detectable excretion of riboflavin metabolite in either urine or milk. Table 3 shows that, even had substance $I$ and the grass metabolite been present, the Floridin, which was routinely used in the urine analysis, would have prevented their interfering. It is noteworthy that of the four lyochromes listed in Table 3 , only riboflavin is microbiologically active. Riboflavin was always present in the urine, even of the animals on the riboflavin-deficient diet. Stallfed cows and goats gave, in addition, substance 1 . When the diet of any of these animals was rich in fresh grass, except in autumn, the grass metabolite appeared, in company with riboflavin and substance $\mathrm{I}$.

In attempts to trace the origin of the microbiologically inactive lyochromes fresh-cut grass was fed in summer to a young Ayrshire bull and to a lactating female goat confined in metabolism crates. Each received in a gelatine capsule $2 \mathrm{~g}$ riboflavin by dosing 


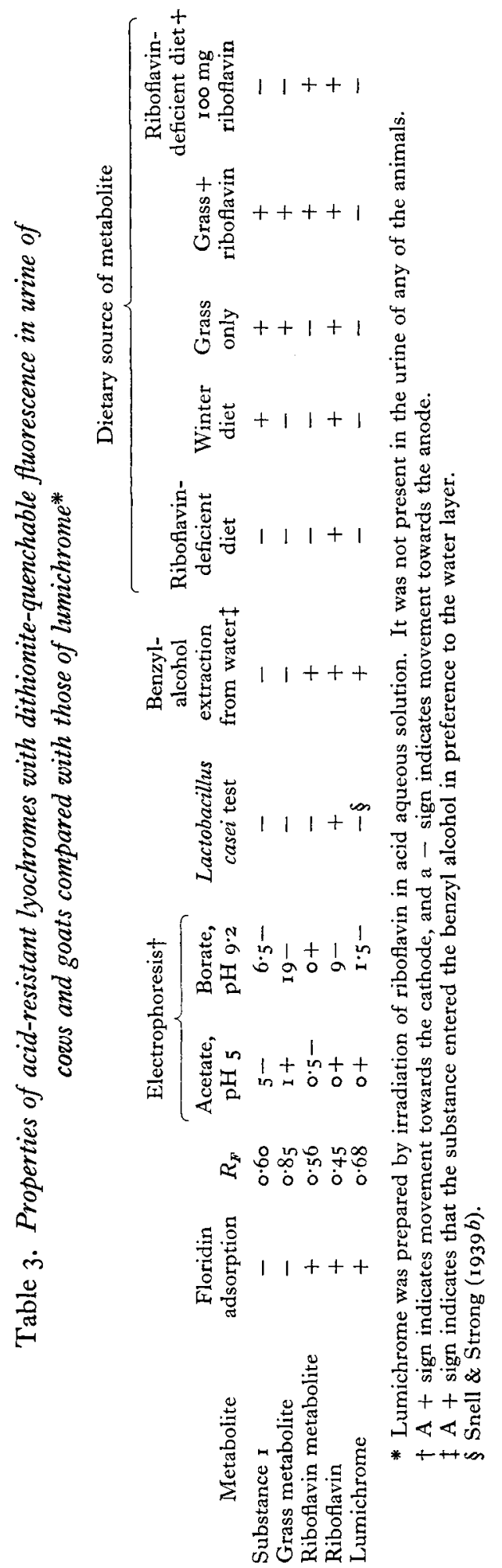


gun. The urines still showed riboflavin, substance $\mathrm{I}$ and the grass metabolite but none of their concentrations was increased. However, a new lyochrome was present in addition as a result of the oral dose of riboflavin. This new substance is shown as riboflavin metabolite in Table 3 where its properties were recorded. Like riboflavin it was extractable from water by benzyl alcohol and was adsorbed by Floridin, but it was microbiologically inactive. The acid-treated milk from the goat contained riboflavin together with the riboflavin metabolite. The milk was yellow and this colouring must have been due to the riboflavin metabolite because the microbiological activity of the acid-treated milk was only slightly increased. This riboflavin metabolite was found again later in urine and milk of goats dosed with roo mg riboflavin. A dose of only $30 \mathrm{mg}$ was too small to produce any effect on either urine or milk. Yellow milk produced by dosing cows, goats and sheep with riboflavin was reported by Pearson \& Schweigert ( 1947) who noted that the increase of colour was accompanied by an increase of substances with a riboflavin-like fluorescence but without microbiological activity. Pearson \& Schweigert have suggested that the riboflavin metabolite might be lumichrome, but Table 3 shows that it cannot be.

In January the urine from four Ayrshire cows at the West of Scotland Agricultural College was examined and grass metabolite was found in the urine of one of them. These cows were receiving grass silage and freshly cut marrowstem kale. It was possible that the grass metabolite arose from the kale but this hypothesis had to be discarded because, when a goat was fed for a week on nothing but fresh-cut kale from the same field, no grass metabolite appeared in its urine. Thus it is probable that the grass metabolite came from the grass silage.

By the method already described, lyochromes were extracted from the urine of four cows which had been grazing for several weeks of summer. By chromatography on paper and electrophoresis the extract was found to contain riboflavin, substance I and the grass metabolite. By using four $19 \times 27$ in. no. 31 paper chromatograms hanging lengthwise, about $10 \mathrm{mg}$ of the grass metabolite were isolated from the urine of these cows and crystallized from water as yellowish-brown needles melting at $\mathrm{I} 84^{\circ}$. The grass metabolite was slightly soluble in cold water and more readily in hot water. It was unaffected by treatment with Takadiastase at $\mathrm{pH} 4.6$ but was evidently labile to weak alkali, for on paper electropherograms it split into three substances, one of which had the same mobility as riboflavin, if the buffer was borax of $\mathrm{pH} 9 \cdot 2$. It moved as a single spot if the buffer was acetate of $\mathrm{pH}_{5}$. Its spectral absorption (Fig. 3 ) in the Unicam SP 500 Spectrophotometer showed a sweeping increase from the visible to the ultraviolet with a peak at $225 \mathrm{~m} \mu$ and very little absorption throughout the longer visible wavelengths. There were suggestions of shoulders at 265 and $370 \mathrm{~m} \mu$. The grass metabolite gave a white ash, and fusion with metallic sodium showed it to contain carbon and nitrogen. The aqueous solution of the ash gave a positive test for iron with either dipyridyl or ferrocyanide, but the positive iron test could perhaps have come from the filter-paper used for its chromatographic preparation. As autumn approached, the grass metabolite disappeared from the urine of cows, presumably owing either to a reduction in the total intake of fresh grass or to some seasonal change in its composition. Studies of the grass metabolite are still in progress. 
Koschara (1934, 1935) isolated two riboflavin-like substances, uroflavin and aquoflavin, from human urine. He also produced evidence for the presence of two other such lyochromes in human urine. It is probable that uroflavin is riboflavin but the relationship of Koschara's other lyochromes to those now described is a matter of conjecture.

Whitby $(195 \mathrm{I}-2)$ isolated riboflavinyl glucoside from rat liver, but it does not appear from its $R_{F}$ value in Crammer's (1948) system, from its spectral absorption or from its acid lability that it could be the same as any of the urinary lyochromes we have found.

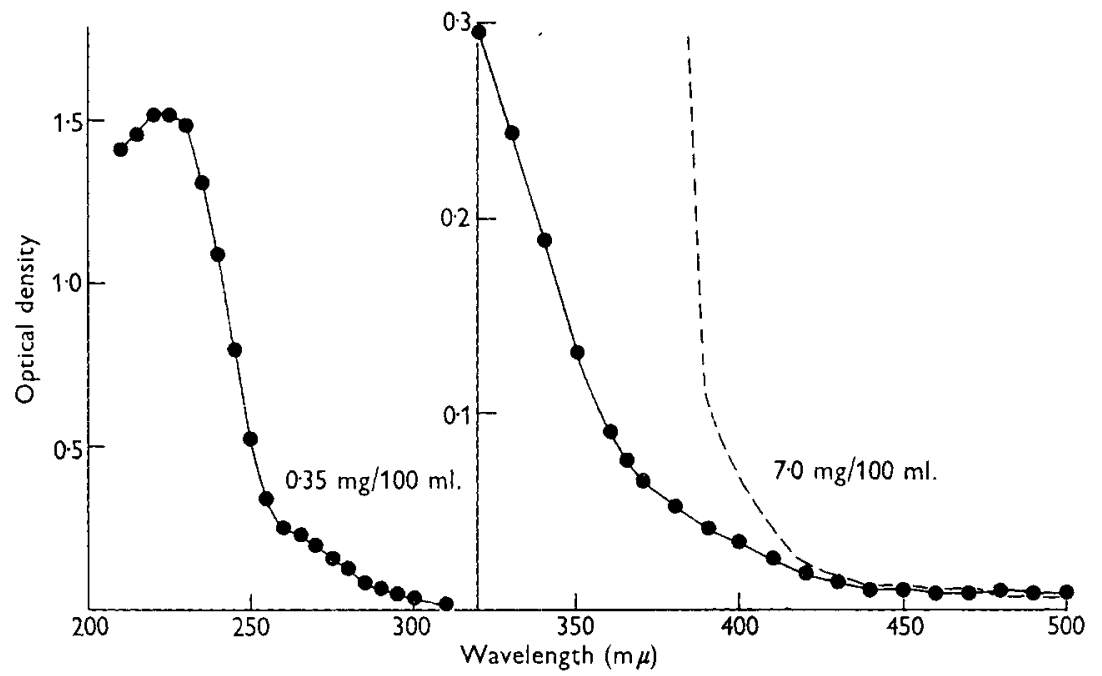

Fig. 3. Absorption spectrum of the grass metabolite in aqueous solution. To obtain readings at wavelengths shorter than $320 \mathrm{~m} \mu$ the solution had to be diluted from 7.0 to $0.35 \mathrm{mg} / 100 \mathrm{ml}$., so that the scale of density is compressed for readings at wavelengths less than $320 \mathrm{~m} \mu$. The broken line represents the absorption after reduction by dithionite.

\section{Nitrogen and riboflavin balances}

In Table 4 are the mean daily nitrogen and the mean daily riboflavin intakes, outputs, and balances of the four goats. In calculating the balances of riboflavin, the riboflavin in the faeces was ignored for the same reasons as the faecal lysine was ignored in the experiment of Edwards \& Darroch (1956). The balances of nitrogen were positive in goats nos. 2 and 3 , very slightly negative in no. I and negative in no. 4. Goat no. 4 had a poor appetite and did not eat the synthetic mixture well. The balances of riboflavin in goats nos. I and 2 were negative, thus indicating synthesis by microbial symbionts in these two goats. In goats nos. 3 and 4 the riboflavin balances were positive, these animals having been supplemented with riboflavin at the rate of $15 \mathrm{mg} /$ day.

A feature of Table 4 is that the output of riboflavin in the milk was equal to the output in the urine. In Table 5 the concentrations of nitrogen and riboflavin in urine, milk and faeces are listed, together with the ratios of riboflavin to nitrogen in each of them for all four animals averaged over the whole period of the experiment. The ratios of riboflavin to nitrogen in all three fall within a narrow range. It might be thought that this constancy is in some way due to the riboflavin being of bacterial origin, were it not for the fact that animals nos. 3 and 4 received adequate supplements of this vitamin. 
Vol. 12

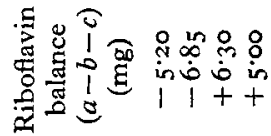

8

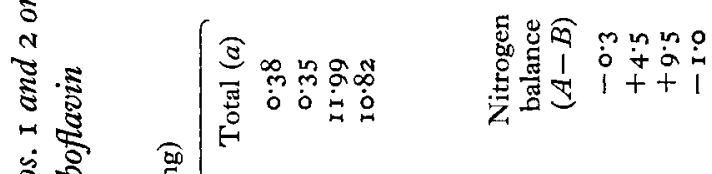

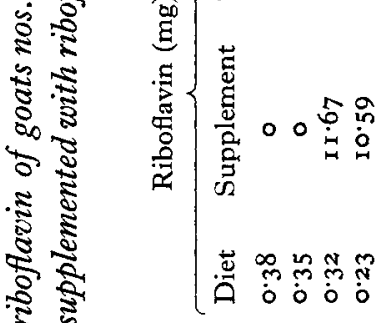

ह : $: \widetilde{8}$

8ू है

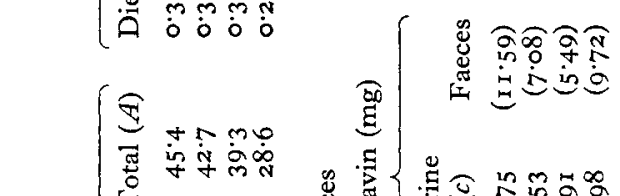

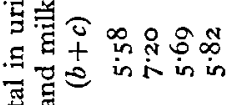

焉

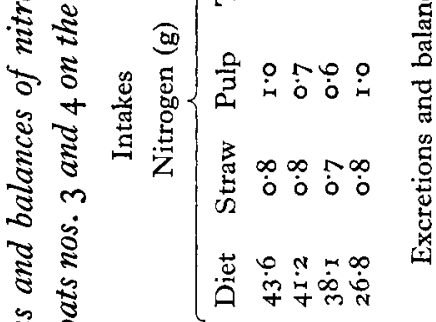

तर

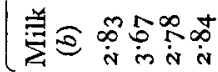

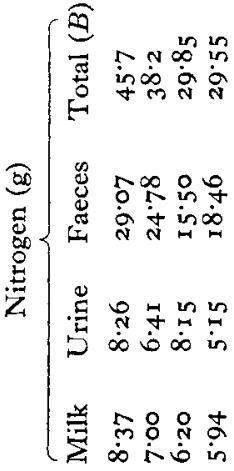

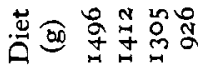

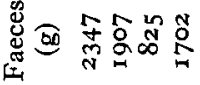

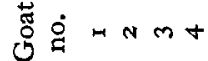

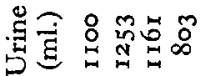

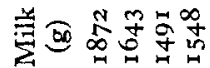

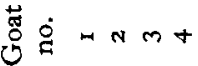




\section{Milk yields}

The milk yields which are depicted in Fig. 4 showed no marked diminution as a result of the riboflavin-deficient diet, and the earlier experiments of Edwards \& Darroch (1956) showed that the diet did not alter the composition of the goat's milk as compared with the milk of the same or other goats on normal rations.

Table 5. Concentrations of riboflavin and nitrogen in milk, urine and faeces of goats nos. I and 2 on the riboflavin-deficient diet and of goats nos. 3 and 4 on the same diet supplemented with riboflavin

\begin{tabular}{|c|c|c|c|c|c|c|c|c|c|}
\hline \multirow{3}{*}{$\begin{array}{c}\text { Goat } \\
\text { no. }\end{array}$} & \multicolumn{3}{|c|}{ Riboflavin } & \multicolumn{3}{|c|}{ Nitrogen } & \multicolumn{3}{|c|}{ riboflavin value } \\
\hline & & Urine & Faeces & Milk & Urine & Faeces & - & ${ }^{2}+0_{0}$ & \\
\hline & $(\mu \mathrm{g} / \mathrm{ml})$. & $(\mu \mathrm{g} / \mathrm{ml})$. & $(\mu \mathrm{g} / \mathrm{g})$ & $(\mathrm{mg} / \mathrm{ml})$. & $(\mathrm{mg} / \mathrm{ml})$. & $(\mathrm{mg} / \mathrm{g})$ & Milk & Urine & Faeces \\
\hline I & $1 \cdot 51$ & $2 \cdot 50$ & 458 & $4 \cdot 48$ & $7 \cdot 5 \circ$ & $12 \cdot 3^{8}$ & 0.34 & 0.33 & 0.37 \\
\hline 2 & $2 \cdot 23$ & $2 \cdot 8 \mathrm{I}$ & $3 \cdot 33$ & $4^{26}$ & $5 \cdot 12$ & $13 \cdot 00$ & 0.52 & 0.55 & 0.26 \\
\hline 3 & I $\cdot 86$ & 2.50 & $6 \cdot 26$ & $4 \cdot 16$ & $7 \cdot 02$ & 18.78 & 0.45 & 0.36 & 0.33 \\
\hline 4 & $1 \cdot 83$ & 3.94 & $5 \cdot 52$ & 4.06 & $7 \cdot 22$ & $12 \cdot 20$ & 0.45 & 0.55 & 0.45 \\
\hline
\end{tabular}

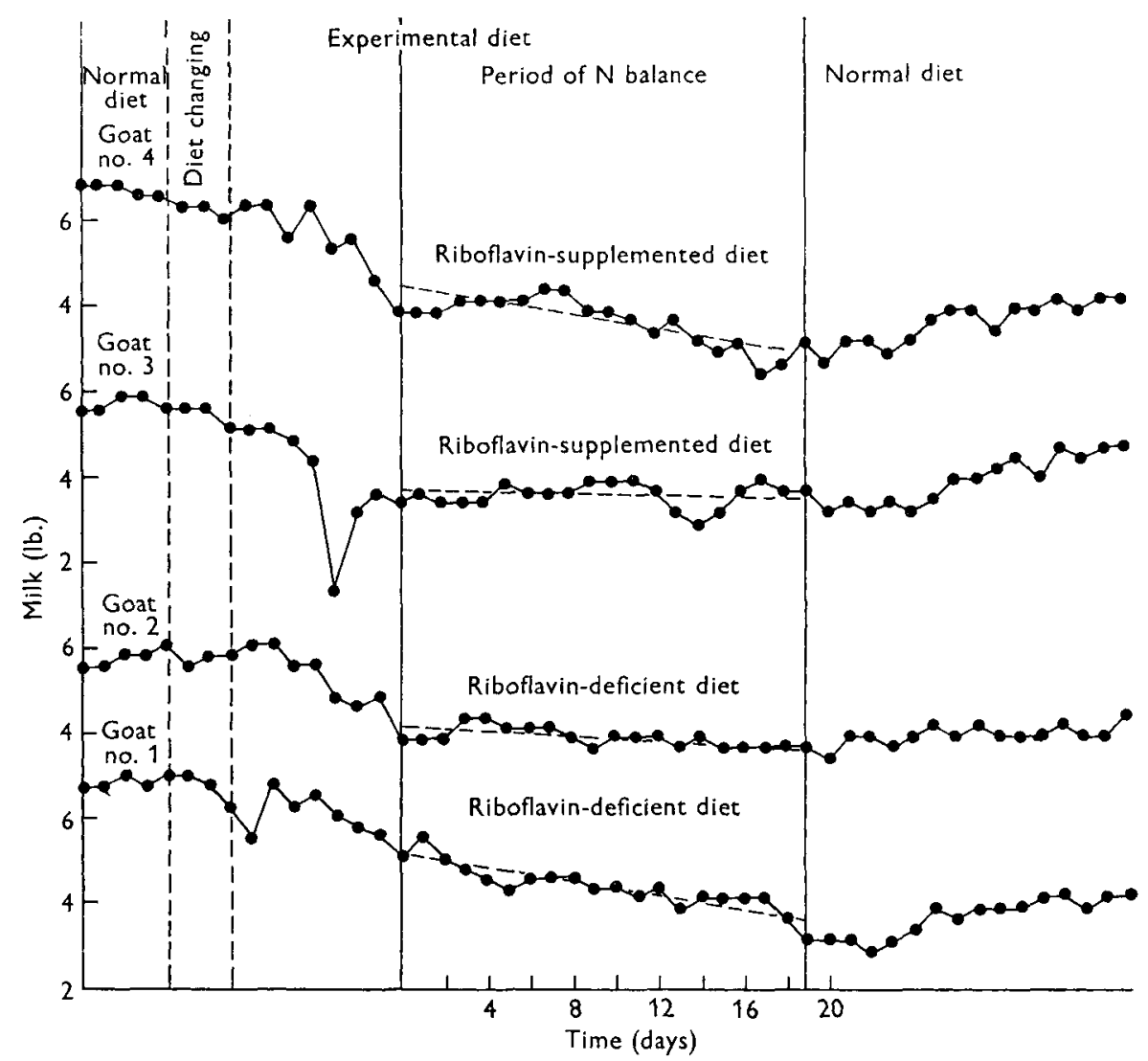

Fig. 4. Milk yields of goats. The straight lines are the regression lines of the milk yields $(y)$ against days $(x)$. Their equations are: goat no. $\mathrm{x}, y=5.09-0.085 x$; goat no. $2, y=4.09-0.034 x$; goat no. 3 , $y=3.59-0.016 x$; goat no. $4, y=4.40-0.093 x$. 
The regression equations of the milk yields (included in Fig. 4) showed a more rapid rate of decline of milk yield for goats nos. I and $4(0.085$ and $0.093 \mathrm{lb}$./day) than for the other two goats, nos. 2 and $3(0.034$ and $0.016 \mathrm{lb}$./day). Thus the two goats with the larger rates of decline of milk yield had negative nitrogen balances, whereas the two with the much smaller rates of decline of milk yield had positive nitrogen balances. When the rates of decline of the milk yields are all considered, their order is found to have been the inverse of that of the nitrogen balances. Nevertheless, the negative balance of goat no. I was small and the animal could be considered to have been in nitrogen equilibrium. Indeed, the 2-day nitrogen balances showed that goat no. I alternated between positivity and negativity. Goat no. $\mathrm{I}$ had the best appetite of all the four goats and would have eaten more of the synthetic mixture if its allowance of it had been increased.

Table 6. Comparison of the milk for 27 weeks of the year 1956 of goats fed on a normal ration with the yields of the same goats in 1957 during which the riboflavin-deficient diet was given for 16 out of the 27 weeks, all yields being reckoned from the peak of lactation

\begin{tabular}{|c|c|c|c|c|}
\hline $\begin{array}{c}\text { Goat } \\
\text { no. }\end{array}$ & $\begin{array}{l}\text { No. of } \\
\text { lactation }\end{array}$ & $\begin{array}{c}\text { Initial } \\
\text { yield } \\
\text { (lb./week) }\end{array}$ & $\begin{array}{c}\text { Rate of } \\
\text { decline } \\
\text { (lb./week) }\end{array}$ & $\begin{array}{l}\text { Total for } \\
27 \text { weeks } \\
\text { lactation } \\
\text { (lb.) }\end{array}$ \\
\hline \multicolumn{5}{|c|}{ I 956 lactation } \\
\hline I & $3^{\text {rd }}$ & $49 \cdot 7$ & $-1 \cdot 45$ & 795 \\
\hline 2 & Ist & $37 \cdot 6$ & $-I \cdot I 3$ & 588 \\
\hline 3 & ist & $4 I^{\circ} 0$ & $-1 \cdot 26$ & 633 \\
\hline 4 & ist & $38 \cdot 4$ & $-r \cdot 22$ & 575 \\
\hline \multicolumn{5}{|c|}{ I957 lactation } \\
\hline $\mathbf{I}$ & $4^{\text {th }}$ & $43 \cdot I$ & $-\mathrm{I} \cdot 04$ & 772 \\
\hline 2 & 2nd & $36 \cdot 2$ & -0.78 & 684 \\
\hline 3 & and & $37 \cdot 0$ & -0.84 & 683 \\
\hline 4 & 2nd & 40.5 & $-I \cdot 05$ & 694 \\
\hline
\end{tabular}

It might be thought that a diet such as the one used in this experiment would cause a rapid deterioration of the animals' ability to produce milk. It is therefore interesting to compare the milk yields of the animals used in these experiments with the yields of the same animals in their previous lactation (Table 6). Though the goats were subjected to the deficient diet for 16 of the 27 weeks considered in the table, it did not prevent the yields of goats nos. 2, 3 and 4 in their second lactation from exceeding the yields in their first lactation. It was during these 16 weeks that the nitrogen balances were determined. The daily rates of decline of yields recorded in Table 6 show that the persistency of lactations was not impaired by the diet. The rates of decline were calculated as the slopes of straight lines fitted by the method of least squares to the milk yields beginning with the peak of lactation of each animal.

\section{Xanthine oxidase in milk}

Since riboflavin is a constituent of xanthine oxidase which occurs in goat's milk (Modi \& Owen, 1956) the concentration of this enzyme in the milk was measured throughout the experiment. Xanthine oxidase in rat intestine and liver was shown by 
Richert \& Westerfield (1957) to be subject to dietary influences due to the protein, iron and molybdenum contents of the food. Axelrod \& Elvehjem (194I) found that riboflavin intake can limit its production, and Kiermeier \& Capellari (1957) showed that xanthine oxidase in cow's milk increases when the fodder is richer in molybdenum. Xanthine oxidase (Westerfield, Richert \& Higgins, 1956; Mahler, 1956; De Renzo, I956) is a compound of protein, iron, molybdenum and riboflavin, and hence its synthesis in the goats could conceivably have been limited by either the small amount of preformed protein in their diet, or by the absence of preformed riboflavin in the diets of goats nos. I and 2, but in these experiments minerals would not be limiting since the salt mixture contained both iron and molybdenum. The xanthine oxidase of the milk of the goats that received riboflavin supplements was much the same as that of the milk of the unsupplemented pair. Goats nos. I, 2, 3 and 4 gave $0.167 \pm 0.12$ (I 8$), 0.193 \pm$ $0.18(24), 0.250 \pm 0.18$ (I8), and $0.161 \pm 0.08$ (18) units of xanthine oxidase, respectively, the values being means with standard deviations and the figures in parentheses being the numbers of estimations. Since restriction of dietary lysine (Bavetta \& Narrod, 1957) or riboflavin (Axelrod \& Elvehjem, I94I) can diminish the synthesis of xanthine oxidase in rat's liver, the approximate equality of the xanthine oxidase of the supplemented and unsupplemented goats is further evidence of the efficiency of microbial synthesis of both riboflavin and lysine in their digestive tracts.

\section{Rumen contents}

The results (Table 7) show that the concentration of riboflavin in the rumen contents of the deficient animals was much the same as that in the rumen contents of the animals receiving riboflavin supplements, and also much the same as that of other normally fed animals of the same herd. Nevertheless, the riboflavin in the deficient diet was only 0.3 p.p.m. of the dry matter so that considerable synthesis was occurring in the rumen of each deficient animal.

\section{Weights of the animals}

During the last week of the experiment three of the animals were gaining in weight, no. I increasing from 104 to $108 \mathrm{lb}$., no. 2 from 96 to IOI lb. and no. 3 from 87 to $89 \mathrm{lb}$. No. 4 , which had a very poor appetite, declined in weight from 99 to $94 \mathrm{lb}$.

Table 7. Riboflavin (mg/g dry matter) in the rumen contents of the goats on the riboflavin-deficient* diet

\begin{tabular}{|c|c|c|c|c|c|c|}
\hline \multirow{3}{*}{$\begin{array}{l}\text { Goat } \\
\text { no. }\end{array}$} & & \multicolumn{4}{|c|}{ Day of experiment } & \multirow{3}{*}{$\begin{array}{c}4 \text { months } \\
\text { later, } \\
\text { a.m. }\end{array}$} \\
\hline & & \multicolumn{2}{|c|}{ I $3^{\text {th }}$} & \multicolumn{2}{|c|}{ 2oth } & \\
\hline & Diet & a.m. & p.m. & a.m. & p.m. & \\
\hline $\left.\begin{array}{l}1 \\
2\end{array}\right\}$ & Riboflavin-deficient & $\{\overline{28 \cdot 3}$ & $\stackrel{15 \cdot 6}{-}$ & $\begin{array}{l}29 \cdot 8 \\
17 \cdot 8\end{array}$ & $\begin{array}{l}44 \cdot 4 \\
32 \cdot 6\end{array}$ & $\begin{array}{l}12 \cdot 6 \\
19 \cdot 4\end{array}$ \\
\hline $\left.\begin{array}{l}3 \\
4\end{array}\right\}$ & $\begin{array}{l}\text { Riboflavin-deficient } \\
\text { + riboflavin }\end{array}$ & $\{\overline{6 \cdot 3}$ & $26 \cdot 3$ & $\begin{array}{r}32 \cdot 2 \\
6 \cdot 3\end{array}$ & $25^{\circ}$ & $\begin{array}{l}14 \cdot 1 \\
24 \cdot 2\end{array}$ \\
\hline
\end{tabular}

* The diet contained $0.3 \mu \mathrm{g}$ riboflavin/g dry matter. Four other female goats from the same herd but fed on beans, oats, dried grass and hay had $10.2,36 \cdot 7,10.7$ and $11 \cdot 0 \mu \mathrm{g}$ riboflavin/g dry matter in the rumen. 


\section{DISCUSSION}

It is of interest to compare the rate of synthesis of riboflavin in these experiments with earlier estimates from other laboratories. Thus Johnson, Maynard \& Loosli (I94I) found $\mathrm{I} \cdot 5 \mu \mathrm{g}$ riboflavin/g milk from cows eating hay containing $2 \cdot 9 \mu \mathrm{g}$ riboflavin/g dry matter. This riboflavin content of the milk was unchanged by a dietary supplement of a yeast by-product rich in riboflavin. Even rations very deficient in riboflavin did not decrease the amount in the milk of goats on a purified ration. The milk yields of the goats of Johnson et al. (194I) declined much more rapidly than did their yields of riboflavin so that abnormally large concentrations of riboflavin in the milk resulted. It is plain from the paper of Johnson et al. (194I) that their goats did not thrive on the deficient ration, probably because it was devoid of long roughage. It may also have been deficient in certain minerals because at that time, I94I, the need of animals for zinc and molybdenum was not known. McElroy \& Goss (1939) found that cows on a ration very poor in riboflavin had about as much riboflavin in their milk as did cows receiving normal winter rations. Their cows, therefore, behaved in this respect as did our goats. McElroy \& Goss provided some of the first evidence that the rumen was an important site of synthesis when they found that rumen contents of sheep and cows were much richer in riboflavin than the diet. Hunt, Kick, Burroughs, Bethke, Schalk \& Gerlaugh (I94I) showed that the rumen of the steer was a site of synthesis when the ration was poor in riboflavin, but their figures also seem to show that when there was plenty of riboflavin in the ration it suffered some destruction in the rumen. Such a phenomenon is not unexpected when it is considered that rumen bacteria would probably degrade, at least in part, an excess of riboflavin. The same seems to have occurred in our supplemented goats, for their milk was no richer in riboflavin than that of the deficient goats. Probably the rumen figures for the supplemented animals represent a balance between bacterial synthesis and bacterial destruction of riboflavin similar to the balance of protein synthesis and destruction found in the rumen by various authors whose work has been reviewed by Owen (1947, 1951). Such a balance may be the reason for the lack of variability of the ratios of riboflavin to nitrogen in milk, urine and faeces shown in Table 5 .

Farmers have for a long time believed that spring grass is superior in nutritive value to autumn grass of the same species (Corbett, 1957). Our experiments indicate that the precursor of the grass metabolite constitutes yet another chemical difference between spring and autumn grass.

\section{SUMMARY}

I. A ration was devised that was deficient in riboflavin but adequate in other respects for ruminants, and methods suitable for estimating riboflavin in milk, urine, faeces, food and rumen contents were worked out. Two goats were given the ration alone and two others the ration together with riboflavin supplements at the rate of I $5 \mathrm{mg} /$ day. For I9 consecutive days on the ration, balances of nitrogen and riboflavin were studied.

2. One of the deficient goats was in positive $\mathrm{N}$ balance $(+4.5 \mathrm{~g} \mathrm{~N} /$ day), the other 
showed a very small negative balance $(-0.3 \mathrm{~g} \mathrm{~N} /$ day), but in each of these animals the output of riboflavin in urine and milk greatly exceeded the dietary intake of riboflavin, in the former by $5.2 \mathrm{mg}$ and in the latter by $6.9 \mathrm{mg} /$ day. Both goats, therefore, were synthesizing riboflavin.

3. The two supplemented goats, one of which was in positive $(+9.5 \mathrm{~g} \mathrm{~N} /$ day) the other in small negative $\mathrm{N}$ balance $(-\mathrm{I} \circ \mathrm{g} \mathrm{N} /$ day) excreted riboflavin in milk, urine and faeces in amounts similar to those excreted by the unsupplemented animals and thus showed positive balances of riboflavin of $6 \cdot 3$ and $5.0 \mathrm{mg} /$ day.

4. The ratios of riboflavin to $\mathrm{N}$ in urine, milk and faeces ranged from 0.26 to 0.55 .

5. The milk yields of the goats were satisfactorily maintained, and the four goats showed rates of decline of yield in the inverse order of their nitrogen balances, the most positive nitrogen balance being associated with the slowest decline of yield. The yields of animals on the deficient ration compared favourably with those of the same goats in their lactation of the previous year on a conventional ration.

6. The xanthine oxidase in the milk was unaffected by the presence or absence of dietary ribollavin.

7. The concentration of riboflavin in the rumen contents of the deficient animals indicated that synthesis of riboflavin was taking place in the rumen.

8. In the urine of goats on the deficient diet, riboflavin was present by itself. In the urine of goats and cows on winter rations another lyochrome, substance $I$, was also present. Cattle and goats eating nothing but fresh grass showed three lyochromes in their urine: riboflavin, substance $\mathbf{I}$ and grass metabolite.

9. In autumn the grass metabolite disappeared from the urine of grazing cows.

10. The grass metabolite was isolated from urine of cows in crystalline form and some of its properties are described.

Ir. Dosing goats with massive quantities of riboflavin produced yet another lyochrome, riboflavin metabolite, in both urine and milk.

12. Of the four urinary lyochromes only riboflavin itself is microbiologically active.

We thank Miss S. McLauchlan, Miss M. Lightbody and Miss E. S. Taylor for skilled technical assistance and Miss S. Hirst for help with the management of the animals. We also thank Mr W. Nisbet of the staff of the Physiology Department of this Institute through whose advice and help electrical stability of the fluorimeter was achieved.

\section{REFERENCES}

Axelrod, A. E. \& Elvehjem, C. A. (194I). F. biol. Chem. 140, 725 .

Barton-Wright, E. C. \& Booth, R. G. (1943). Biochem. F. 37, 25.

Bavetta, L. A. \& Narrod, S. A. (1957). Proc. Soc. exp. Biol., N.Y., 94, 289.

Bessey, O. A., Lowry, O. H. \& Love, R. H. (1949). F. biol. Chem. 18o, 755.

Corbett, J. L. (1957). N.A.A.S. quart. Rev. 37, 93 .

Crammer, J. L. (1948). Nature, Lond., 16r, 349.

Crossland, A. C., Owen, E. C. \& Proudfoot, R. (1958). Biochem. F. 68, I4P.

De Renzo, E. C. (1956). Advanc. Enzymol. 17, 293.

Edwards, D. C. (1955). F. Dairy Res. 22, 232.

Edwards, D. C. \& Darroch, R. A. (1956). Brit. F. Nutr. ro, 286.

Ferrebee, J. W. (1940). F. clin. Invest. 19, 251 .

Greene. R. D. \& Black, A. (1937). F. Amer. chem. Soc. 59, I 820. 
AUDREY CROSSLAND, E. C. OWEN AND R. PROUDFOOT

Metabolism of RIBoflavin

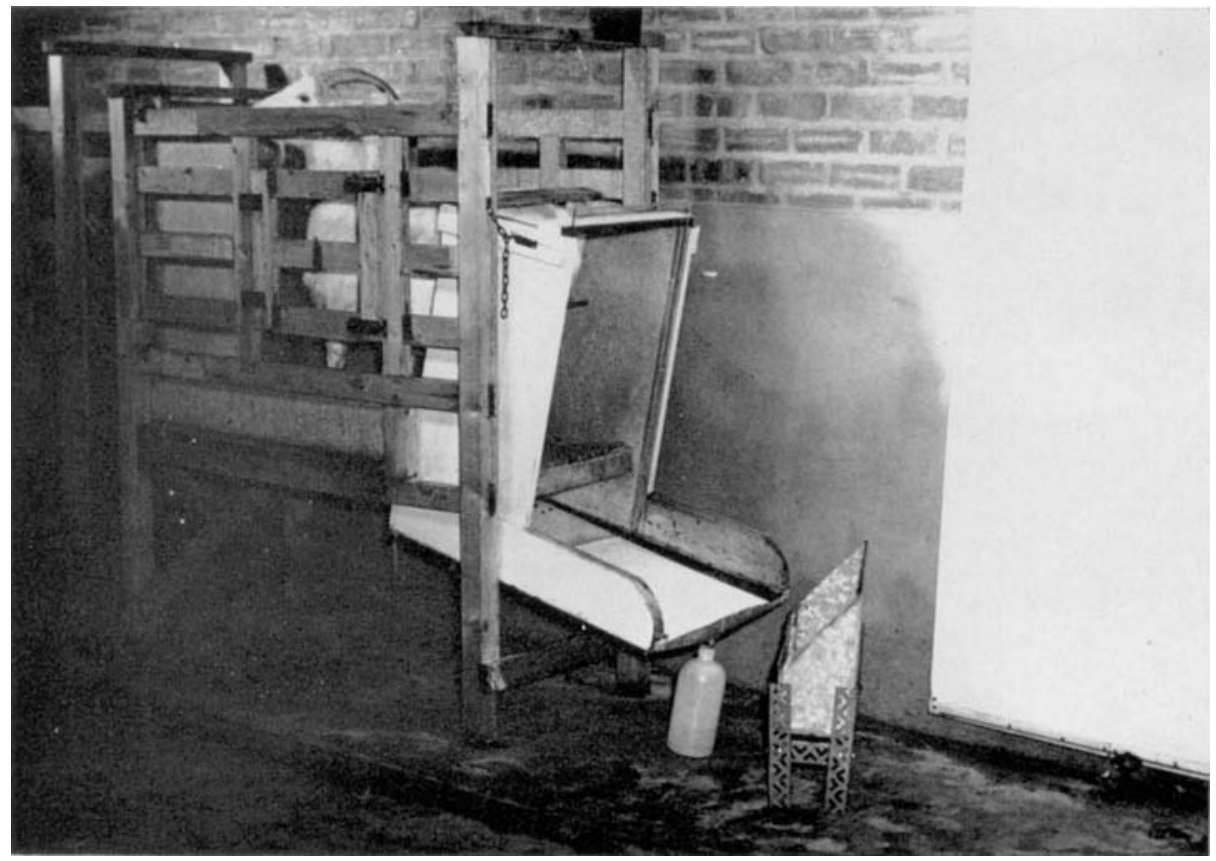

British Fournal of Nutrition, Vol. I2, No. 3 
AUDREY CROSSLAND, E. C. OWEN AND R. PROUDFOOT

Plate 2

METABOLISM OF RIBOFLAVIN

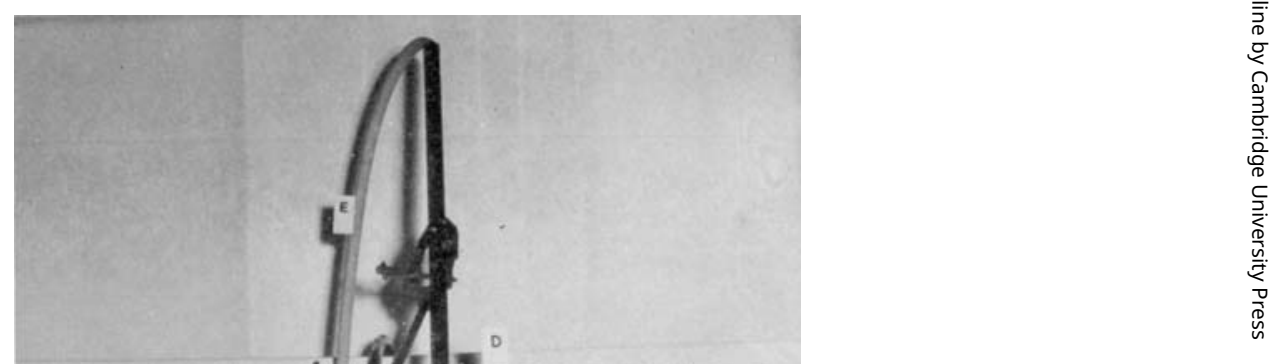

British Fournal of Nutrition, Vol. I2, No. 3 
Holloway, D. H. (1956). Electrical Times, 18 October.

Hunt, C. H., Kick, C. H., Burroughs, E. W., Bethke, R. M., Schalk, A. F. \& Gerlaugh, P. (I94I). F. Nutr. 2I, 85 .

Johnson, P., Maynard, L. A. \& Loosli, J. K. (194I). F. Dairy Sci. 24, 57.

Kawerau, E. (r951). Biochem. F. 48, 281 .

Kiermeier, F. \& Capellari, K. (1957). Naturwissenschaften, 44, 69.

Koschara, W. (1934). Hoppe-Seyl. Z. 229, ro3.

Koschara, W. (1935). Hoppe-Seyl. Z. 232, 101.

Lewis, J. R. \& Gorham, P. R. (1947). Canadian F. Res. 25, Sect. F, p. 133.

Lowry, O. H. (1948). F. biol. Chem. 173, 677.

McElroy, L. W. \& Goss, H. (1939). F. biol. Chem. 130, 437.

Mahler, H. R. (1956). Advanc. Enzymol. 17, 233.

Modi, V. V. \& Owen, E. C. (1956). Nature, Lond., 178, i 120.

Owen, E. C. (1947). F. Dairy Res. 15, I42.

Owen, E. C. (I95I). F. Dairy Res. r8, I I3.

Owen, E. C. (1954). F. Dairy Res. 21, 408.

Pearson, P. B. \& Schweigert, B. S. (1 947). I. Nutr. 34, 443.

Richert, D. A. \& Westerfield, W. W. (1957). F. biol. Chem. 227, 533.

Snell, E. E. \& Strong, F. M. (1939a). Industr. Engng Chem. (Anal.), II, 346.

Snell, E. E. \& Strong, F. M. (x939b). Enzymologia, 6, I86.

Westerfield, W. W., Richert, D. A. \& Higgins, E. S. (1956). In A Symposium on Inorganic Nitrogen Metabolism. Function of Metalloflavo-Proteins. [W. McElroy and B. Glass, editors.] Baltimore: The John Hopkins Press.

Whitby, L. G. (I951-2). Biochem. F. 50, 433 .

Zittle, C. A., Dellamonica, E. S., Custer, J. H. \& Rudd, R. K. (1956). F. Dairy Sci. 39, 522.

\section{EXPLANATION OF PLATES}

Plate I

Photograph of metabolism crate for lactating goat (see text). The door at the side is for access when the animal is being milked. The faeces and urine either fall on to the perforated polyvinyl-chloride plate or are deflected on to it by the upright glass plate. The inclination of the polyvinyl-chloride plate can be varied by varying the length of the chains, one of which is visible in the picture. The faeces bin has been drawn aside to show the end of the funnel beneath the polyvinyl-chloride plate and the Polythene bottle for receiving the urine.

\section{Plate 2}

Photograph of pump used for obtaining samples of rumen contents through the mouth. The electric motor $A$ repeatedly breaks the partial vacuum, produced by the water pump, by rotating the glass stopcock connecting flask $B$ to the atmosphere. Flask $B$ causes intermittent reduction of pressure in flask $C$ so that rumen contents are drawn into it through the translucent pliable plastic tube $E$ held in position in the goat's mouth by the T-piece $D$ made of copper tubing. The horizontal arms of $D$, which are rubber-covered, serve as handles to hold the goat's mouth open both while $E$ is being passed down the oesophagus, through the remaining arm of $D$, and while the sample of rumen contents is being drawn into $C$. The tip of $E$ is of Polythene pierced with three pairs of holes and is sealed at the end. 